\title{
MANAGEMENT OF AEOLIAN SAND TRANSPORT ON A DIKE, DUNKIRK SEAPORT, FRANCE
}

\begin{abstract}
Antoine Tresca ${ }^{123}$, Marie-Hélène Ruz ${ }^{123}$, Stéphane Raison ${ }^{4}$, and Pascal Grégoire ${ }^{5}$
The shoreline of Dunkirk Seaport partly consists of a macrotidal beach oriented WSW-ENE backed by a $6 \mathrm{~km}$ long coated dike called "digue du Braek". Aeolian sand transport was estimated on asphalt by means of sand traps. Also, time-averaged wind speed profiles were measured using cup anemometers under various wind velocities and directions along a transversal profile on the dike and the upper beach. High rates of sand transport enabled the setup of different kinds of experimental windbreaks on asphalt, in order to test potential dune formation on this kind of substrate. Under oblique onshore winds, it was regularly observed that amounts of sand captured in the traps placed on the dike were more important than those in traps placed on the upper beach. These results were related to sand sources: windblown sand captured on the dike originated from the coastal dunes developed at the dike toe, while sand trapped on the upper beach came from the tidal zone were aeolian transport is limited by complex intertidal bartrough topography. It also appeared from the topographic surveys carried out on the windbreaks that although their location seemed to play a major role on the amount of sand captured, fences and synthetic fabrics deployed on sandy surfaces were also able to trap windblown sand on the seaport dike.
\end{abstract}

Keywords: Aeolian sand transport; Windbreaks; In situ measurements; Dike; Nord-Pas-de-Calais; France

\section{INTRODUCTION}

The great complexity of natural coastal systems has always made it difficult to predict aeolian sand transport (Bauer et al., 1996). Within beach-foredune environments, wind-blown sand is controlled by several parameters (Nickling and Davidson-Arnott, 1990; Bauer and Davidson-Arnott, 2002; DavidsonArnott, 2005; Davidson-Arnott et al., 2005), including wind velocity and direction, fetch effect, size of the sediment supply, vegetation height and density, and moisture content. On macrotidal coasts, width of the intertidal zone tends to increase sediment supply, but aeolian sand transport is limited by complex intertidal beach-trough topography (Anthony et al., 2009). Deterministic models of aeolian transport (Bagnold, 1941) are often poor predictors of effective transport measured on beaches, due to the large amount of parameters to consider (Bauer et al., 1996). Human actions tend to add even more complexity to the coastal systems, particularly in highly developed areas, where foredunes have sometimes been replaced by buildings or seafront promenades in the most touristic sites. These developing projects can unbalance sediment budgets, causing beach erosion by canceling beachforedune exchanges, or by creating wave reflection on hard structures. Shore protection structures can also enhance aeolian sediment transport when a beach exists seaward of the structure, causing windblown sand accumulation in urban, touristic or economic areas (Nordstrom et al., 2000; Jackson and Nordstrom, 2011).

Dunkirk Seaport has been developing since the end of the 1950s on land reclaimed from the sea, resulting in a totally artificial shoreline, partly consisting on a $6 \mathrm{~km}$ long shore parallel structure. A 750 $\mathrm{m}$ long jetty has favoured sand accumulation and upper beach progradation, resulting in dune formation seaward of this asphalt coated dike. These dunes represent a new source of wind-blown sand, which is exported landward, on a road and in a maritime basin, requiring costly dredging and removal operations. In 2010, $10000 \mathrm{~m}^{3}$ of sand was removed from a $500 \mathrm{~m}$ long road landward of the dike. As underlined by Jackson and Nordstrom (2011), few studies have been conducted on interactions between human modifications to the shoreline and aeolian sand transport, except those related to nourishment (Davison et al., 1992; Draga, 1983; Eitner and Ragudstki, 1994; Van der Wal, 2004), dune building or dune stabilization (Mendelssohn et al., 1991; Miller et al., 2001). Very few studies have described aeolian processes on dikes (Nordstrom and Arens, 1998), and although effects of fencing are well documented (Anthony et al., 2007; Ruz and Anthony, 2008; Grafals-Soto and Nordstrom, 2009; Grafals-Soto, 2012), no studies have been carried out on their efficiency on dikes. As a consequence, the present study intends to quantify aeolian sand transport on the asphalt coated dike of Dunkirk

\footnotetext{
${ }_{1}^{1}$ Université Lille Nord de France, CS 90005, F-59044, Lille Cedex, France

${ }^{2}$ ULCO, LOG, 28 avenue Foch, 62930 Wimereux, France

${ }^{3}$ CNRS, UMR8187, 28 avenue Foch, 62930 Wimereux, France

${ }^{4}$ DEAL Réunion, 2 rue Evariste de Parny, BP 2002, 97821 Le Port Cedex, France

${ }^{5}$ Dunkerque Port, port 2505, 2505 route de l'écluse Trystram, 59140 Dunkerque, France
} 
Seaport, and to test windbreaks usually installed on the upper beach on asphalt in order to favour windblown sand accumulation.

\section{STUDY SITE}

Located near the Belgian border, the $15 \mathrm{~km}$ shoreline of Dunkirk harbour is mainly orientated WSW-ENE (fig. 1). The coast is dominantly exposed to moderate oblique offshore to alongshore winds from a southwesterly window, followed by a significant oblique onshore component from the NorthEast (fig. 1). Seventy percent of the winds are below $8 \mathrm{~m} \cdot \mathrm{s}^{-1}$, while strong winds $\left(>12 \mathrm{~m} \cdot \mathrm{s}^{-1}\right)$ only account for $6 \%$ of the regime. The eastern half of this shoreline is characterized by a 150 to $500 \mathrm{~m}$-wide macrotidal beach (spring tidal range $=5.45 \mathrm{~m}$ ), backed by a $6 \mathrm{~km}$ long asphalt coated dike called "Digue du Braek". The tidal zone is characterized by a ridge and runnel morphology and is directly linked to the dike along almost its entire length. Longshore drift, eastward directed (Cartier and Héquette, 2011), is interrupted by a $750 \mathrm{~m}$ long jetty, contributing to sand accumulation and upper beach progradation in the eastern part (Tresca et al., 2012). In this area, a 20 to $40 \mathrm{~m}$ wide upper beach is backed by 3 to $4 \mathrm{~m}$ high dunes located at the dike toe, peaking at $8 \mathrm{~m}$, and covering a surface of about $13000 \mathrm{~m}^{2}$. These upper beach and dunes are characterized by fine to medium sand $(0.25 \mathrm{~mm}<$ $\mathrm{Mz}<0,47 \mathrm{~mm})$, well- $(\mathrm{Si}<0.5 \phi)$ to very well-sorted $(\mathrm{Si}<0.3 \phi)$.
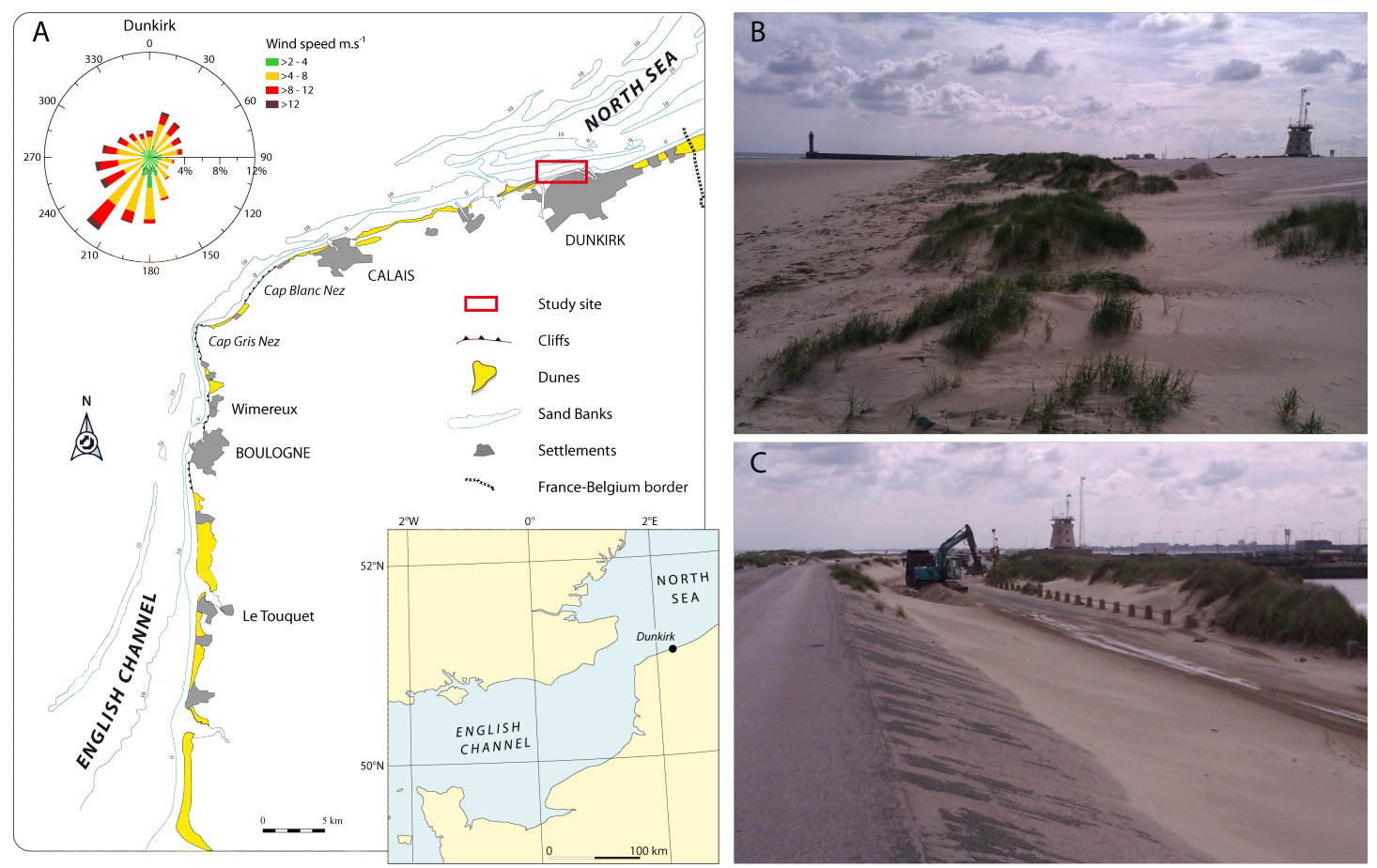

Figure 1. (A)Study site, wind conditions (1991-2007) at the station of Dunkirk, and ground photographs of (B) dune development at the dike toe and (C) sand accumulation landward of the dike.

\section{METHODS}

Sand transport rates were estimated using wedge-shaped sand traps (Nickling and McKennaNeuman, 1997) (fig. 2 - I) fixed on a $5 \mathrm{~mm}$ thick steel sheet. Wind speed was measured every 5 seconds using 8 or 12 cup anemometers (depending on the number of masts ( 2 or 3 ) deployed along a shore transversal profile) linked to a data logger. The anemometers were placed at heights of $0.25 \mathrm{~m}, 0.50 \mathrm{~m}$, $0.75 \mathrm{~m}$ and $1 \mathrm{~m}$, except on the mast where mean wind speed at $2 \mathrm{~m}$ was averaged (mast 3 for seaward experiments, mast 1 for landward experiments), replacing the anemometer placed at $0.75 \mathrm{~m}$. 


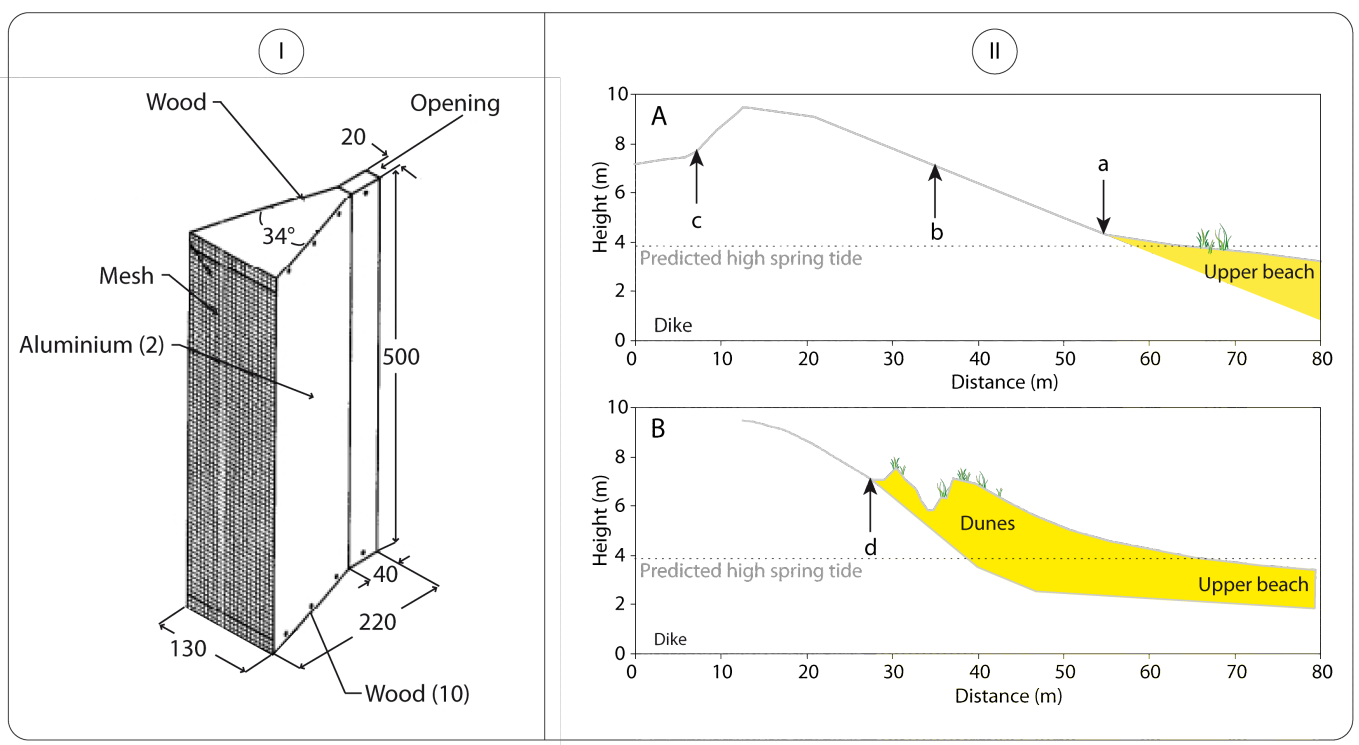

Figure 2. (I) Schematic description of the vertical sand trap used in the field and (II) location of the experimental windbreaks on 2 cross-shore profiles of the dike above the upper-beach and behind dune development at the dike toe.

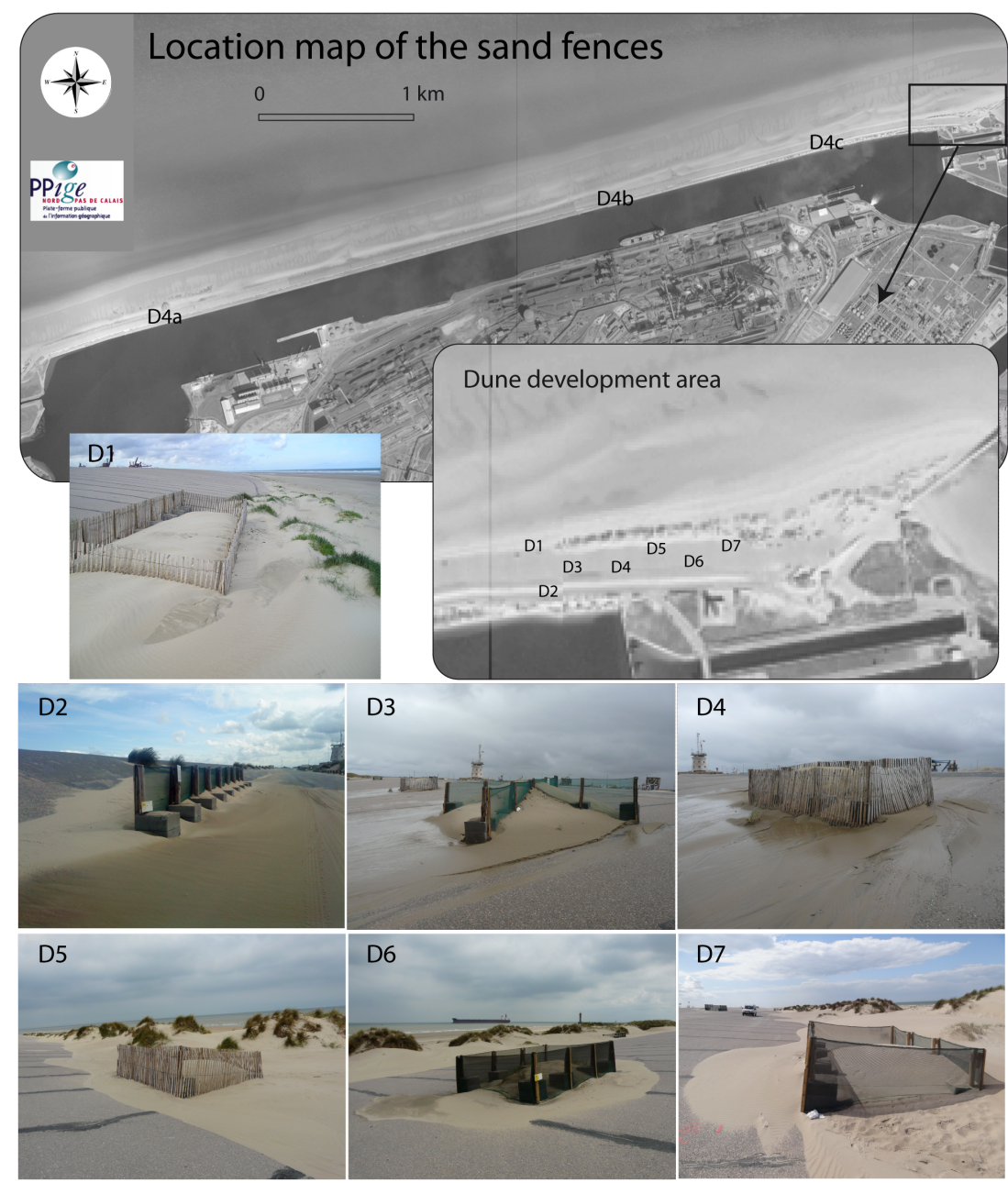

Figure 3. Location map and ground photographs of the experimental structures. D4, D4a, D4b and D4c are the same and have the same location on the dike profile. 
Sand trapping experiments with a sampling duration of 10 minutes were carried out in spring and late winter 2011, for various wind conditions. The sampling period was imposed by the weak storage capacity of traps. The weight of sand obtained was dried, weighted and converted to a rate in $\mathrm{kg} \cdot \mathrm{m}^{-1} \cdot \mathrm{h}^{-1}$. Only the result of three experiments with representative wind conditions are described in this paper. General wind direction was recorded at Dunkirk MétéoFrance Weather Station, $1 \mathrm{~km}$ east of the shore transversal profile where the experiments were conducted.

Windblown sand accumulation on the dike was tested using sand fences (wooden slats and synthetic fabrics) with a height of $1.2 \mathrm{~m}$ and a porosity of $50 \%$. As it was impossible to make holes in the coated surface, chestnut posts inserted into concrete blocks were used to fix them to the ground. In February 2011, ten experimental structures were positioned on the dike at different locations: dike toe (fig. 2 - IIA), dike landward (fig. 2 - IIC) and seaward slopes (fig. 2: IIB - above upper beach and IIC - behind deflation corridors in dune developing at the dike toe). Field observations have shown that most of the windblown sand transfers occur in the eastern part of the dike, where dunes have developed at the dike toe (Tresca et al, 2012). Seven windbreaks were installed in this restricted area, while the 3 others were in the middle and in the western part of the dike (fig. 3). Sand volume was monitored every month, within as well as around each structure, using a Differential Global Positioning System (DGPS) with errors within $\pm 5 \mathrm{~cm}$ for height and $\pm 3 \mathrm{~cm}$ for distance. Digital Elevation Models (DEMs) were generated using standard terrain modelling software based on points interpolation techniques (points spaced 2-4 m apart), and volumes were calculated (size of the monitored area divided by net volume change). A $10 \mathrm{~cm}$ empirically derived margin of error, covering both operator and interpolation errors was applied to the raw data. The figures included this margin of error. The overall wind conditions that prevailed over the survey periods were determined from MétéoFrance wind records from Dunkirk station, 1 to $5 \mathrm{~km}$ east of the survey areas.

\section{RESULTS}

\section{Aeolian sand transport}

Sand transport rates and wind profiles for three experiments are shown in fig. 4. The 26/05/2011, winds were longshore to obliquely offshore from west-southwest, and mean wind speed over the 10minute run at the top of $2 \mathrm{~m}$ mast 3 was relatively high with $11.3 \mathrm{~m} . \mathrm{s}^{-1}$. Instruments were deployed at three points from the upper beach to the upper part of the dike seaward slope (fig. 4aIII). As the upper beach was not reached by tide and there had been no precipitation during the previous 7 days, surface moisture of the upper beach was zero. Trap M3 intercepted $28 \mathrm{~kg} \cdot \mathrm{m}^{-1} \cdot \mathrm{h}^{-1}$ of sand, while M2 and M1 trapped significantly more with 95 and $93 \mathrm{~kg} \cdot \mathrm{m}^{-1} \cdot \mathrm{h}^{-1}$, respectively (fig. 4aII). For these alongshore wind conditions, traps M1 and M2 were in contact with the upper beach - the main sand source, and therefore aeolian fetch distance played a major role in filling these traps. M3 however,was situated on the dike and was not directly connected to any sand source.

The $03 / 03 / 2011$, low moisture value $(0.4 \%)$ of the upper beach was once again explained by the absence of precipitation in the 2 days preceding the experiment. This 10-minute run (fig. $4 \mathrm{~b}$ ) was conducted under northeast winds blowing obliquely onshore, with a mean wind speed of $9.8 \mathrm{~m} . \mathrm{s}^{-1}$. Instruments were positioned at three points from the upper beach to the upper seaward slope of the dike (fig. 4bIII). Wind speeds increased onshore, with a difference of $1.3 \mathrm{~m} . \mathrm{s}^{-1}$ at the $0.5 \mathrm{~m}$ level between masts 1 and 3 (fig. 4bII) over a distance of $50 \mathrm{~m}$. The variation in the shape of the wind profiles, with a steeper slope above the $0.75 \mathrm{~m}$ level, suggested an increasing shear velocity near the ground. This shape was more pronounced at mast M1, which can be interpreted as airflow compression towards the top of the dike. This wind speed-up has been highlighted in many studies conducted on dune slopes (Svasek and Terwindt, 1974; Chistiansen and Davidson-Arnott, 2004; Hesp et al., 2005; Walker et al., 2009). The dike slope played the same role here. Sand interception was significant on the dike, with 31 and 37 $\mathrm{kg} \cdot \mathrm{m}^{-1} \cdot \mathrm{h}^{-1}$, respectively, in traps located next to masts M3 and M2, while the trap next to mast M1 intercepted only $6 \mathrm{~kg} \cdot \mathrm{m}^{-1} \cdot \mathrm{h}^{-1}$ (fig. 4bI). This result can be explained by the fact that, for these wind conditions, sand sources were different according to the location of the traps. Sand trapped in M1 came from the foreshore, where aeolian transport was segmented due to complex intertidal bar-trough topography (Anthony et al., 2009). Moisture content played here a major role, and reduced aeolian sand transport. For this wind direction, sand traps M2 and M3 were located behind the partly vegetated dunes, where the sand was dry and therefore more easily mobilized by wind. 


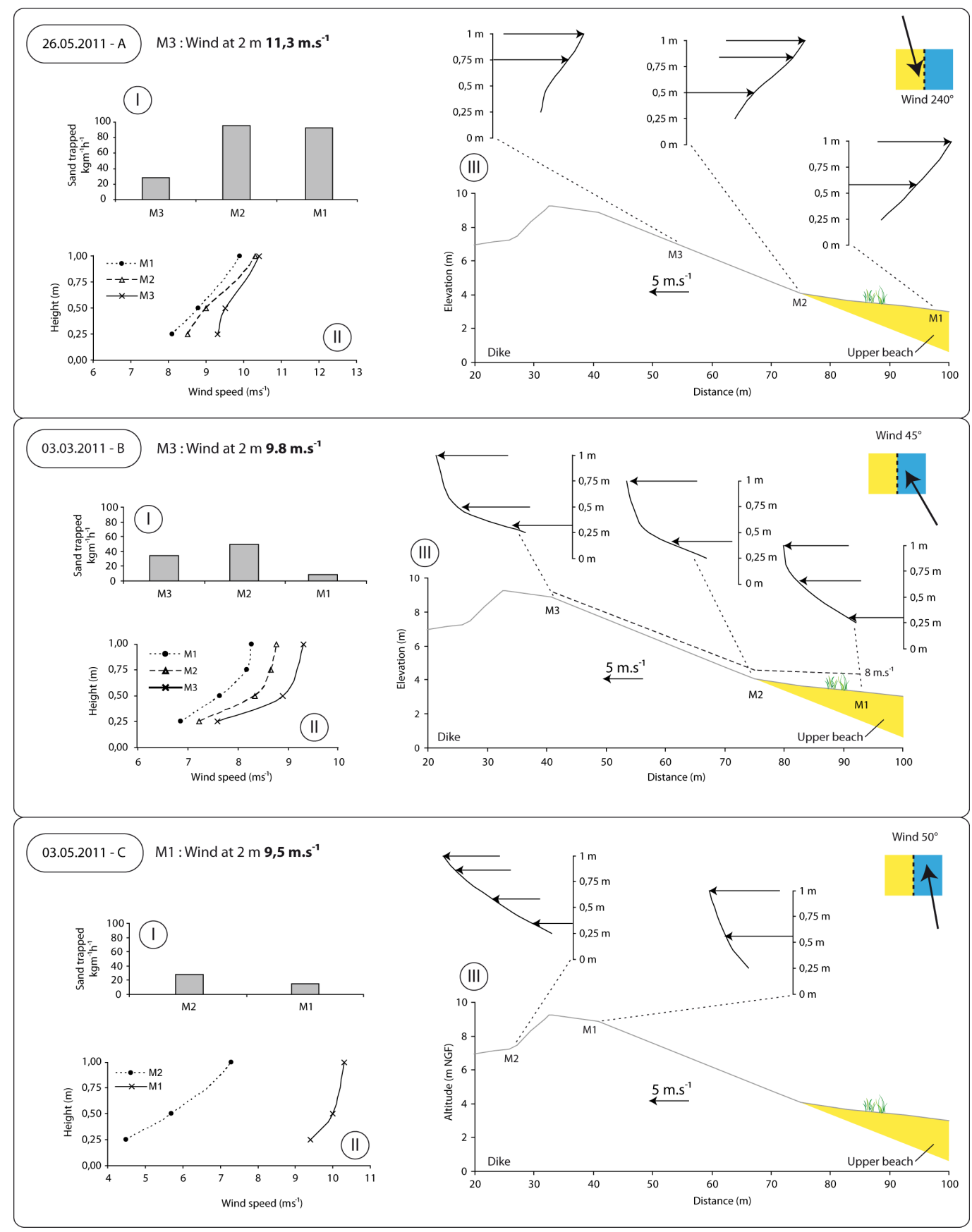

Figure 4. Sand transport rates and wind profiles during three $10 \mathrm{~min}$ wind events $(A)$ on the seaward slope by oblique offshore to alongshore dominant winds, (B) on the seaward slope by oblique onshore winds and (C) on the top and the landward slope by oblique onshore to alongshore winds.

The 03/05/2011 experiment (fig. 4c) was conducted under oblique onshore to almost alongshore winds, where the mean wind speed recorded at the top of the $2 \mathrm{~m}$ mast 1 was $9.5 \mathrm{~m} . \mathrm{s}^{-1}$. Instruments were deployed at two points: the upper seaward slope, and the base of the landward slope (fig. 4cIII). Moisture content of the upper beach was nil, as there had been no rain for 3 days. Wind profiles showed a sharp deceleration in the lee of the dike, with a difference of $5 \mathrm{~m} \cdot \mathrm{s}^{-1}$ at the $0.25 \mathrm{~m}$ level, over a distance of only $15 \mathrm{~m}$ between masts 1 and 2 (fig. 4cII). This deceleration had a consequence on sand trapping rates. The trap next to M1 intercepted $15 \mathrm{~kg} \cdot \mathrm{m}^{-1} \cdot \mathrm{h}^{-1}$, while the one next to M2 intercepted twice as much, with $28 \mathrm{~kg} \cdot \mathrm{m}^{-1} \cdot \mathrm{h}^{-1}$ of sand in this deposition area (fig. $4 \mathrm{cI}$ ), as wind conditions weakened in that sheltered location. Although mean wind speed and moisture content were relatively similar to the 03/03/2011 experiment, sand interception was weaker for the 03/05/2011 one. This could be explained 
by local flow and sand transport deviation from the regional wind because of topographic steering of oblique alongshore airflow (Walker and Hesp, in press). As the traps used in this study had a unidirectional opening, they were likely to miss sand interception in the case of significant fluctuations in wind direction. Simple measurements of wind velocity did not enable the measurement of such 3D effects, and high frequency measurements of airflow should be conducted in order to assess this hypothesis.

\section{Potential dune development experiments}

Six of the 10 structures were monitored over a 309 day period (February to August 2011), and were all located in the eastern part of the dike, near the dike-toe dunes. As the 4 other windbreaks were damaged, their survey period was consequently shorter. Net volumes for the 6 longer periods are shown in tab. 1 .

\begin{tabular}{|c|c|c|c|}
\hline \multicolumn{4}{|c|}{$\begin{array}{l}\text { Table 1. Net and normalized volume change } \\
\text { of } 6 \text { structures over a } 10 \text { months survey }\end{array}$} \\
\hline & $\begin{array}{l}\text { Net volume } \\
\text { change }\left(\mathrm{m}^{3}\right)\end{array}$ & Surface $\left(\mathrm{m}^{2}\right)$ & $\begin{array}{l}\text { Normalized } \\
\text { volume } \\
\left(\mathrm{m}^{3} \cdot \mathrm{m}^{2}\right)\end{array}$ \\
\hline \multicolumn{4}{|c|}{ Entire area } \\
\hline D1 & 99,61 & 241,17 & 0,41 \\
\hline D2 & 28,87 & 153,05 & 0,19 \\
\hline D3 & 17,29 & 171,07 & 0,10 \\
\hline D4 & 4,37 & 148,58 & 0,03 \\
\hline D6 & 4,78 & 113,85 & 0,04 \\
\hline D7 & 37,3 & 115,37 & 0,32 \\
\hline \multicolumn{4}{|c|}{ Within the fence } \\
\hline D1 & 25,4 & 30,47 & 0,83 \\
\hline D2 & $x$ & & $x$ \\
\hline D3 & 9 & 15,30 & 0,59 \\
\hline D4 & 4,16 & 13,67 & 0,3 \\
\hline D6 & 3,9 & 15,31 & 0,25 \\
\hline D7 & 10,21 & 10,78 & 0,95 \\
\hline
\end{tabular}

Considering the sand volumes monitored within the windbreaks, the most efficient structure was D7 (synthetic fabrics installed behind the dunes), with a normalized differential volume of $0.95 \mathrm{~m}^{3} . \mathrm{m}^{2}$, followed by D1 (wooden slats at the beach-dike contact) with $0,83 \mathrm{~m}^{3} \cdot \mathrm{m}^{2}$. Less efficient windbreaks were D4 and D6, corresponding to synthetic fabrics and wooden slats installed on the seaward slope of the dike, with a similar amount of 0,3 and $0,25 \mathrm{~m}^{3} \cdot \mathrm{m}^{2}$, respectively, of sand. D2 was a linear sand fence, thus it was impossible to calculate the amount of sand trapped inside. If we consider the entire survey areas (sand accumulated by as well as around the fence), D1 showed a net sand gain of $100 \mathrm{~m}^{3}$, which represented a net normalized volume of $0.41 \mathrm{~m}^{3} . \mathrm{m}^{2}$, suggesting moderate overall accretion over the 10months survey period. D4 and D6 were very stable considering the $0,1 \mathrm{~m}^{3} \cdot \mathrm{m}^{2}$ margin of error.

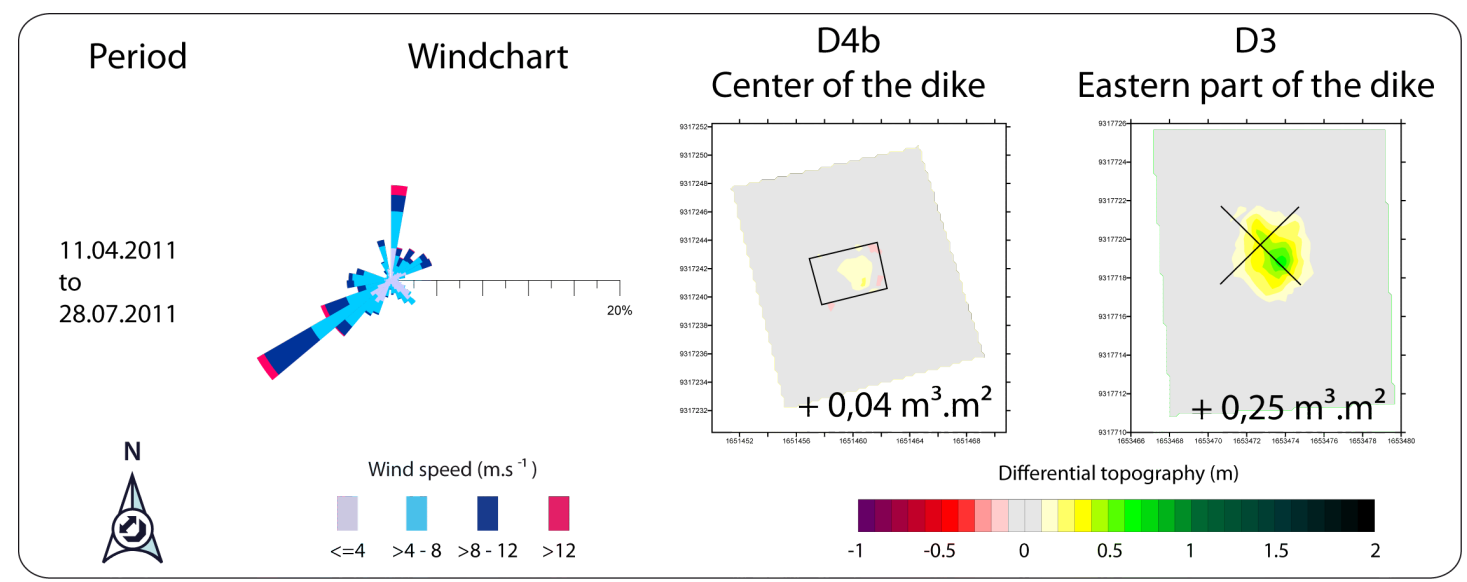

Figure 5. DEMs and net cumulative normalized volume change on two experimental structures placed on the seaward slope of the dike: (D4b) $3 \mathrm{~km}$ west from the jetty, (D3) in the eastern part of the dike, near the jetty. Black limits represent fences. 


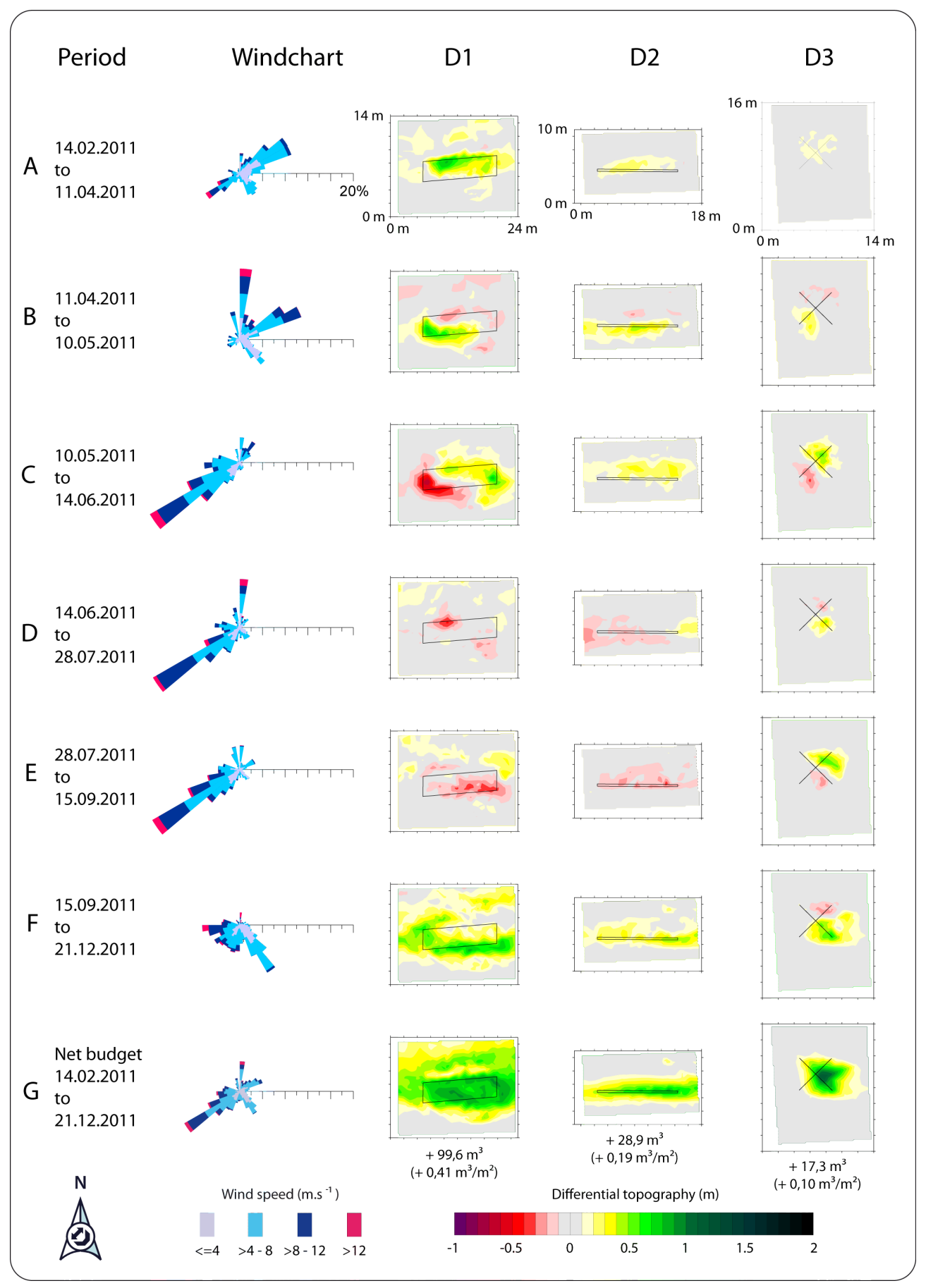

Figure 6. Successive DEMs and net cumulative volume changes on the 3 experimental structures: D1 at the beach/dike contact; D2 on the leeward slope; D3 on the seaward slope. Wind charts are represented for each period. Black limits represent fences. Accretion/Erosion scale shows predominance of accretion (progressively yellow then green colour) on the three areas.

Two structures located on the middle of the seaward slope of the dike (location -b- fig. 2 II) are compared on figure 5. The experimental windbreak D4b was installed in the central part of the dike, and D3 was erected in the eastern part (fig. 3). It appears that the structure D4b did not trap sand at all during this 108 day survey, whereas D3 gained $0.25 \mathrm{~m}^{3} . \mathrm{m}^{2}$. This result can be explained by the fact that, in the center of the site, the foreshore was directly connected to the dike, and there was no upper beach at high tide. As a consequence, sand source for aeolian sand transport was very limited. On the contrary, in the eastern part of the site, field experiments (fig. 4) showed that the presence of partly 
vegetated dunes at the dike toe enhanced aeolian sand transport on the dike under oblique onshore winds from the NE conditions. Therefore, the presence of this sand source explains the better efficiency of structure D3 compared to structure D4b.

The successive morphological changes and net volumes during the entire survey period of three different experimental windbreaks D1, D2 and D3 are shown in fig. 6. It is obvious that sand fences played a significant role in sand accumulation within the three areas, as the progressively yellow then green colour shows. Deposition occurred mostly inside and around the structures, especially at D2 and D3, while we can notice at DEM D1, the development on the upper beach of a line of three embryo dunes parallel to the wooden slats, was rapidly colonized by pioneer vegetation (fig. 6G). This parameter partly explains the greater amount of sand trapped in this area relative to the others, particularly for windbreaks installed on the dike without contact with upper beach or dunes. Moreover, sand fences installed on the upper seaward slope of the dike (D3 in this example) recorded a loss of sand owing to run off towards the dike toe during wet weather. The accretion pattern reflected both wind conditions and the effect of the fences on local wind flow. At the beginning of the survey (fig. 6A and $6 \mathrm{~B}$ ), oblique onshore winds from a broad north-easterly window prevailed, which led upper beach and "dike-toe dunes" sand to be exported toward the south and to be captured respectively by D1 and D2/D3. Then, winds from a narrow south-westerly window moved sand from the south to the north of the fences, showing that in most cases, deposition occurred in the lee of the structures (fig. 6C). During periods D and E (fig. 6), experimental structures were exposed to almost the same wind regime than in period C, but recorded much less accretion. For this wind direction, as shown earlier in this paper with sand transport field experiments, sand sources were limited, while onshore to oblique onshore winds were able to "feed" the structures with sand removed from the beach and the dunes. Moreover, although accretion occurred most of the time leeward of the fence, in the case of D3 (fig. 6D), the great proportion of southwesterly winds did not initiate subsequent accumulation at the NE but at the SE, which was the result of the prevalence of northern winds at the end of the period. It was noticeable that a period of traditionally summer recovery on structures installed on the upper beach (Anthony et al., 2007) did not benefit to sand accumulation in this case, where winds from a narrow south-westerly window blew. Much of the sand gain was assured when oblique onshore winds from the NE prevailed, and also during periods when a broad window of various wind directions occurred (fig. $6 \mathrm{~F}$ ).

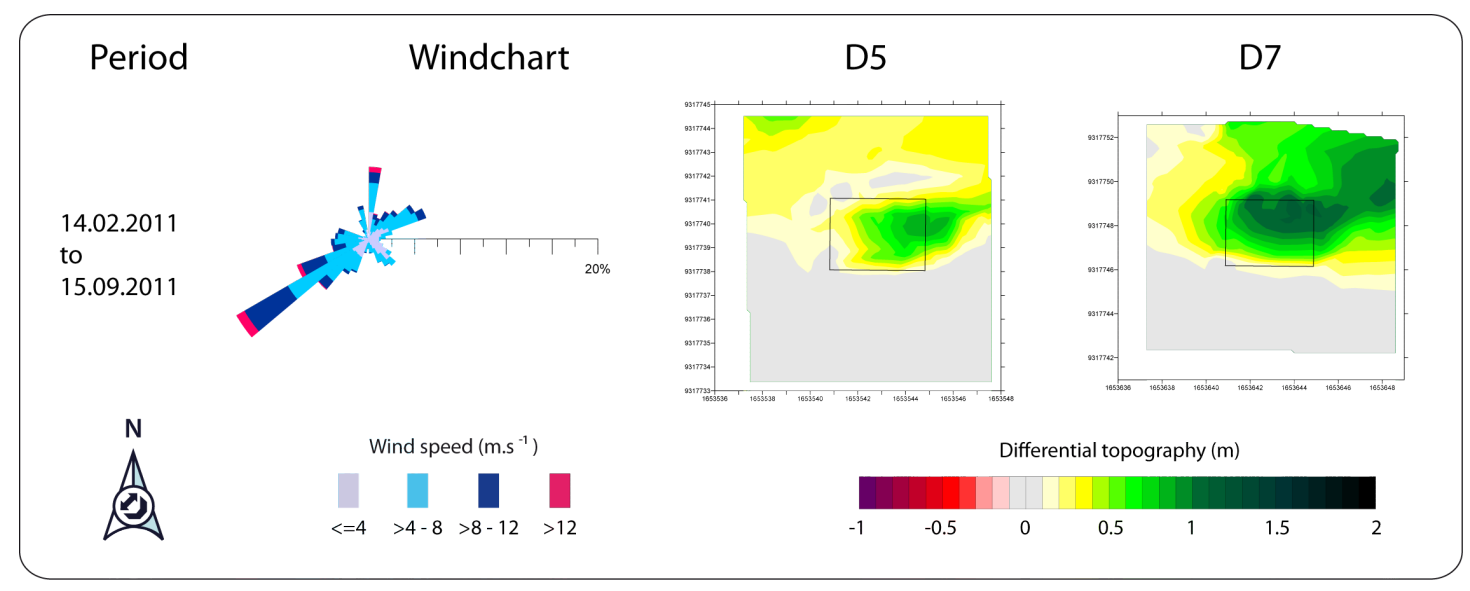

Figure 7. DEMs and budget changes of 2 experimental structures (D5: wooden slats; D7: synthetic fabrics) at the same location on the profile, behind dune development at the dike toe. Black limits represent fences. Accretion/Erosion scale shows predominance of accretion (progressively yellow then green colour) on both plots.

The comparison of two structures of identical size and shape, installed at the same point on the dike profile, behind dunes at the dike toe, and thus both located in the eastern part of the dike, a hundred meters apart, is shown in fig. 7. This seven-month survey showed that amounts of sand trapped greatly differed from one experimental structure to another. At plot D7, the fence was made of synthetic fabrics and trapped $9 \mathrm{~m}^{3}\left(44 \mathrm{~m}^{3}\right.$ on the whole area, i.e. $\left.0.38 \mathrm{~m}^{3} \cdot \mathrm{m}^{2}\right)$, while D5, made of wooden slats, only trapped $5 \mathrm{~m}^{3}\left(21 \mathrm{~m}^{3}\right.$ on the whole area, i.e. $\left.0.18 \mathrm{~m}^{3} \cdot \mathrm{m}^{2}\right)$. In both cases, deposition of sand occurred in the upper-right corner of each fence (north-east), which was the result of dominant winds originating from the south-west. If we consider the area around the fences, accretion took place seaward of the 
structures, that is to say, in the dunes area, but no deposition occurred on the dike, south of the fences. At D5, most of the accumulation was made inside the structure, and accretion was about $0.8 \mathrm{~m}$, while it was about $1.30 \mathrm{~m}$ within and around (north-east) the fence at D7 (fig. 7).

\section{CONCLUSION}

During aeolian sand transport experiments, our observations showed that sand intercepted in the traps was more important on the upper beach than on the dike by dominant longshore to oblique offshore winds. However, under oblique onshore winds from the NE, sand transport seemed to be enhanced on the dike by dune developing at the dike toe in the eastern part of the dike. This great sand source could easily be mobilized by wind, given that in these partly vegetated dunes, sand was much drier compared to the foreshore, where fetch was segmented due to bar-trough differentiation in moisture content. Once the sand had been mobilized and reached the slope of the asphalt dike, wind speed-up encouraged transport over the top of the structure, and deposition occurred landward, in the lee side of the dike. Therefore, it seems important to trap and/or fix sand before it reaches the dike. Differential volume maps of sand accumulation in the experimental structures have shown that the most efficient windbreaks were located in the eastern part of the dike, given that partly vegetated dunes constitute the main sand source for aeolian sand transport. The efficiency of the experimental structures seems to have been influenced by their location on the dike. Windbreaks erected at the beach/dike or beach/dune contact were more able to trap sand than those which were installed in the middle of the dike seaward slope, affected by run off during rain periods. Moreover, the location of the structures, well above high water levels, made them dependent of the wind regime exclusively, unlike sand fences usually erected at the dune toe, where erosion can happen due to wave action (Ruz and Anthony, 2008). These results have shown that it is crucial to identify potential sand sources in order to prevent erosion problems. These experiments will enable Port of Dunkirk to build a management plan of its shoreline, in order to preserve the diversity of landscapes, habitats and species.

\section{ACKNOWLEDGMENTS}

This study was funded by Association Nationale de la Recherche et de la Technologie (ANRT) and the Port of Dunkirk. Field assistance was provided by Vincent Sipka, Adrien Cartier and Aurélie Maspataud.

\section{REFERENCES}

Anthony, E.J., M-H. Ruz, and S. Vanhée. 2009. Aeolian sand transport over complex intertidal bartrough beach topography, Geomorphology, 105, 95-105.

Anthony, E.J., S. Vanhee, M-H. Ruz. 2007. An assessment of the impact of experimental brushwood fences on foredune sand accumulation base don digital elevation models. Ecological Engineering, 31, 41-46.

Bagnold, R.A. 1941. The physics of blown sand and desert dunes. Chapman and Hall (Ed.), London, $265 \mathrm{p}$.

Bauer B.-O., R.G.D. Davidson-Arnott, 2002. A general framework for modeling sediment supply to coastal dune including wind angle, beach geometry and fetch effects. Geomorphology, 49, p. 89108.

Bauer B.O., R.G.D. Davidson-Arnott, K.F. Nordstrom, J. Ollerhead, N.L. Jackson. 1996. Indeterminacy in Aeolian Sediment Transport Across Beaches. Journal of Coastal Research,12 (3), 641-653.

Belly P.Y. 1964. Sand movement by wind. US Army Corps of Engineers, Coastal Engineering Research Center, Tech. Memo., 1, Washington D.C., 38 p.

Cartier, A., Héquette, A., 2011. Variation in longshore sediment transport under low to moderate conditions on barred macrotidal beaches. Journal of Coastal Research SI (ICS 2011), 45 - 49.

Christiansen M.B., R.G.D. Davidson-Arnott. 2004. Rates of landward sand transport over the foredune at Skallingen, Denmark and the role of dune ramp. Danish Journal of Geography, 104 (1), 31-43.

Davidson-Arnott, R.G.D., K. MacQuarrie, T. Aagaard, 2005. The effect of wind gusts, moisture content and fetch length on sand transport on a beach. Geomorphology, 68, 115-129.

Davison, A.T., R.J. Nicholls, S.P. Leatherman, 1992. Beach nourishment as a coastal management tool: an annotated bibliography on developments associated with the artificial nourishment of beaches. Technical communication. Journal of Coastal Research, 8, 984-1022. 
Draga, M., 1983. Eolian activity as a consequence of beach nourishment - observations at Westerland (Sylt), German North Sea coast. Zeitschrift für Geomorphologie, Supplement 45, 303-319.

Eitner, V., G. Ragutski, 1994. Effects of artificial beach nourishment on nearshore sediment distribution (Island of Norderney, Southern North Sea). Journal of Coastal Research, 10, 637-650.

Grafals-Soto, R., 2012. Effects of sand fences on coastal dune vegetations distribution. Geomorphology, 145-146, 45-55.

Grafals-Soto, R., K.F. Nordstrom, 2009. Sand fences in the coastal zone: intended and unintended effects. Environmental Management, 44, 420-429.

Héquette, A., M-H. Ruz, D. Marin, V. Sipka, 2012. Suivi morpho-sédimentaire de l'UG4. Rapport annuel 2011. Laboratoire LOG, ULCO, 45p.

Hesp P.A., R.G.D. Davidson-Arnott, I.J. Walker, J. Ollerhead 2005. Flow dynamics over a foredune at Prince Edward Island, Canada. Geomorphology, 65, 71-84.

Jackson N.L., K.F. Nordstrom. 2011. Aeolian sediment transport and landforms in managed coastal systems : a review. Aeolian research, 3(2), 181-196.

Mendelssohn, I.A., M.W. Hester, F.J. Monteferrante, F. Talbot, 1991. Experimental dune building and vegetative stabilization in a sand-deficient barrier island setting on the Louisiana coast, USA. Journal of Coastal Research 7, 137-149.

Miller, D.L., M. Thetford, L. Yager, 2001. Evaluating sand fence and vegetation for dune building following overwash by Hurricane Opal on Santa Rosa Island, Florida. Journal of Coastal Research 17, 936-948.

Meur-Ferec C., M-H. Ruz. 2002. Transports éoliens réels et théoriques en haut de plage et sommet de dune (Wissant, Pas-de-Calais, France). Géomorphologie,4, 321-334.

Nickling W.G., C. McKenna Neuman. 1997. Wind tunnel evaluation of a wedge-shaped Aeolian sediment trap. Geomorphology, 18, 333-345.

Nickling, W. G. and Davidson-Arnott, R. G. D. 1990. Aeolian sediment transport on beaches and coastal dunes, in Arnott, R.G. D. (Ed.), Proceedings of the Symposium on Coastal Sand Dunes, National Research Council, Ottawa, 1-35.

Nordstrom, K.F., R. Lampe, L.M. Vandemark, 2000. Re-establishing naturally functioning dunes on developed coasts. Environmental Management, 25 (1), 37-51.

Nordstrom, K.F., S.M. Arens. 1998. The role of human actions in evolution and management of foredunes in the Netherlands and New Jersey, USA. Journal of Coastal Conservation, 4, 169-180.

Ruz, M-H., E.J. Anthony. 2008. Sand trapping by brushwood fences on a beach-foredune contact : the primacy of the local sediment budget. Zeitschrift für Geomorphology, 52 (3), 179-194.

Svasek J.N., J.H.J. Terwindt, 1974. Measurements of sand transport by wind on a natural beach. Sedimentology, 21, 311-322.

Tresca, A., M-H. Ruz, P. Gregoire. 2012. Caractérisation du transport éolien sur asphalte à partir de piégeages in situ : le cas de la digue du Braek, Dunkerque. Paralia, Actes colloque JNGCGC 2012 Cherbourg, 503-510.

Van der Wal, D., 2004. Beach-dune interactions in nourishment areas along the Dutch coast. Journal of Coastal Research, 20, 317-325.

Walker I.J., R.G.D. Davidson-Arnott, P.A. Hesp, B.O. Bauer, J. Ollerhead 2009. Mean flow and turbulence responses in airflow over foredunes: new insights from recent research. Journal of Coastal Research SI n $^{\circ}$ 56, pp 366-370.

Walker, I.J., Hesp, P.A. (in press). Fundamentals of Aeolian Sediment Transport: Airflow over dunes. Ch. 11.7, Vol. 11: Aeolian Geomorphology, Treatise on Geomorphology. Elsevier: Oxford. 